\title{
Effect of Black Rice Bran Extract to Decrease Glucose Level of Diabetic Rats
}

\author{
Novita Sari* and Arifah Sri Wahyuni \\ Fakultas Farmasi Universitas Muhammadiyah Surakarta \\ Jl. A. Yani Tromol Pos I, Pabelan Kartasura Surakarta 57102 \\ *e-mail: novita.k11.59@gmail.com
}

\begin{abstract}
Black rice bran is one of processed foods derived from plants and has a decreasing effect of blood glucose levels. Major component of anthocyanin in black rice bran that functions in lowering blood glucose concentration is cyanidin 3-glucoside. Fifteen male rats Sprague-Dawley strain were selected randomly and divided into 5 groups with the same number in each groups. These groups were consisted of normal control, negative control, and black rice bran extract treatment with dose of 50, 100 and $200 \mathrm{mg} / \mathrm{kg}$ of bodyweight (b.w.). Each of them were induced to experience diabetes by alloxan $150 \mathrm{mg} / \mathrm{kg}$ of b.w. Measurement of blood glucose levels was done by using visible spectrophotometer at $546 \mathrm{~nm}$. The samples were collected before and after alloxan injection, and after 4, 7, and 10 days later to observe the changes of blood glucose levels. The results showed that black rice bran at $200 \mathrm{mg} / \mathrm{kg}$ of b.w. was able to lower the glucose levels, which amounted for 131,33 $\pm 8,08 \mathrm{mg} / \mathrm{dL}$ after 10 days of injection.
\end{abstract}

Keywords: Black rice bran, anthocyanin, antidiabetic.

\section{Introduction}

Diabetes mellitus (DM) is one of the health problems caused by the degenerative process. Various epidemiological studies have shown that an increased prevalence of diabetes mellitus (Suyono, 1995). Global Prevalance Of Diabetic predicts an increase of diabetes in the coming years with the prevalence of the growth was two-fold in developing countries. In Indonesia, it is estimated that the number of patients will rise up to 21.3 million in 2030, which was previously only about 8.4 million in 2000 (Wild et al., 2004). As the amount of people with DM gaining every year, it becomes pharmacist duty to educate and prevent this disease in the community.

The accumulation of patients with DM annually causes upsurge of antidiabetic drugs consumption, even though the use of synthetic antihyperglycemic drugs can cause adverse side effect. Nowadays, traditional herbal medicines with minimal detrimental side effect has been developed. One of these drugs comes from plants that have the potential to lower blood glucose levels (Malviya et al., 2010). One of the foods that come from plants and has this ability is black rice bran.

The use of black rice bran as an antihyperglycemic drug in Indonesia has not been developed optimally. Black rice bran has a main component of cyanidin 3-glucoside as the active compound to lower blood glucose levels (Park et al., 2008). In a previous research conducted by Hadi (2015), the accumulation of anthocyanins in black rice bran amounted to $\quad 3.284 \mathrm{mg} / 100 \mathrm{~g}$, whereas research conducted by Suryaningrum (2015) levels of cyanidin 3-O-glucoside in the ethanol extract of black rice bran was $0.012 \%(\mathrm{w} / \mathrm{w})$ more than the ethanol extract of red rice bran. This compound with $200 \mathrm{mg} / \mathrm{kg}$ dose was able to reduce blood glucose concentration in the diabetic nephropathy rat equivalent to normal controls (Nawa 2014). Flavonoid compounds in black rice brand have a mechanism of action in reducing blood glucose levels by stimu-lating insulin secretion and increasing $\mathrm{Ca}^{2+}$ influx in the tissues (Tapas et al., 2008). Flavonoids are able to prompt glucose uptake in tissue and regulate the level of enzyme activity through the carbohydrates metabolism (Brahmachari, 2001).

The purpose of this research was to determine the effect of black rice bran extracts on the reduction of blood glucose levels in diabetic rats. The results of the study were expected to provide information about the benefit of black rice bran extract in reducing 
blood glucose levels. Hence, it can be used as an alternative antidiabetic herbal medicine.

\section{Research Methodology}

\section{Experimental Design}

This research was an experimental study with completely randomized design to determine the effect of black rice bran extract in reducing blood glucose levels in diabetic rats. The tests were carried out by using 15 white Sprague-Dawley strain male rats which were divided into five treatment groups. This study was conducted at the Laboratory of Pharmacology and Clinical Pharmacy Faculty of Pharmacy, Universitas Muhammadiyah Surakarta.

\section{Tools and materials}

a. Tools used in the extraction process were macerator, rotary analytical balance, evaporator, filter paper, Buchner funnel and vacuum pumps, aluminum foil, porcelain bowls, and water bath.

b. Tools used for animals testing were rat cages, scales, drinking places, gloves, masks, centrifuge, vortex, oral sonde, needles, and disposable syringes.

c. Tools used for blood glucose levels measurements were disposable semi-micro cuvette, micropipette size from 0.5 to $10 \mathrm{~mL}$ and $100-$ $1000 \mathrm{~mL}$ (Accura), white tips, blue tips, and UV-Vis spectrophotometer (Star Dust FC * 15), pipette, Beker glass, cuvette and UV-Vis spectrophotometer.

\section{Materials}

Materials used of this research were black rice bran extract, male rats Sprague-Dawley strain weighing 200-300 grams, and reagent Glucose GOD FS kit.

\section{Treatment for Laboratory Animals}

Test animals in this study were male rats 2-3 months old with a weight of 200 to 300 grams that have acclimatized for 7 days. Then, mice were randomly selected and divided into 5 groups with each consisting of 3 rats

- $\quad$ Group I (normal control), fed with pellets and distilled water po

- Group II (negative control) was treated with alloxan and given distilled water as a po

- Group III was treated with an extract of $50 \mathrm{mg} / \mathrm{kg}$ po

- Group IV was treated with an extract of $100 \mathrm{mg} / \mathrm{kg}$ po

- Group V was treated with an extract of $200 \mathrm{mg} / \mathrm{kg}$ po

Rats were weighed every day until the $10^{\text {th }}$ day as a baseline. They were fasted for 8-12 hours on the day before the initial measurement of blood glucose levels (called day 0). Next, group II-V were induced with alloxan $150 \mathrm{mg} / \mathrm{kg}$ of b.w. intraperitoneally. Monitoring of the blood glucose levels was done until the $2^{\text {nd }}$ day after the induction of alloxan. Rats were considered to have diabetes if the concentration of blood glucose was more than $140 \mathrm{mg} / \mathrm{dl}$. The test animals that already have experienced diabetes can be treated with extracts. Analysis of blood glucose concentration were performed on the $4^{\text {th }}, 7^{\text {th }}$, and $10^{\text {th }}$ day.

\section{Determination of Glucose Concentration}

As much as $0.5 \mathrm{ml}$ of blood sample was taken from lateral tail vein and put into microtube. Then, these samples were centrifuged at $13.400 \mathrm{rpm}$ for 30 minutes to obtain the blood serum, which will be used as samples for analysis.

There were blank, standard, and sample solution used in this analysis. All solutions were made by adding $5 \mathrm{ml}$ aquadest, glucose, and blood serum to $500 \mathrm{ml}$ of reagent Glucose GOD FS kit respectively. Then, these mixtures were vortexed and incubated for 10 minutes at $37^{\circ} \mathrm{C}$. The absorbance was read by using spectrophotometer at a wavelength of 546 $\mathrm{nm}$. The data acquired were analyzed by using statistical MS Exel worksheet. 


\section{Results And Discussion}

1. Effect of Black Rice Bran Extracts Toward Decrease of Blood Glucose Level.

Regulation of blood glucose are performed by pancreas by releasing insulin. Therefore, pancreatic damage will result in decline of insulin secretion (Chambpel et al., 2004). Defect in the pancreatic cells can be induced by alloxan. It is a diabetogenic agent, which has the chemical formula 2,4,5,6-pyrimidine trione and unstable in the water. It has a half life of 1.5 minutes at neutral $\mathrm{pH}$ at $37^{\circ} \mathrm{C}$ and produce dialuric acid through redox cycling process that will form peroxide radicals. Through the Fenton reaction, reactive hydroxyl radicals will increase calcium ions level and cause damage to the $\beta$-Langerhans cells (Szkuldeski, 2011). Alloxan dose of 150 $\mathrm{mg} / \mathrm{kg}$ proved to increase the average level of blood glucose up to $300 \mathrm{mg} / \mathrm{kg}$ (Table 1). According to Etuk \& Muhammed (2010), this dosage was shown to increase the glucose concentration in the $75 \%$ population of test animals.

The observation of changes in blood glucose levels were performed on the fourth, $7^{\text {th }}$, and $10^{\text {th }}$ day after the extract treatment. The treatment groups in this study were using 50, 100 , and $200 \mathrm{mg} / \mathrm{kg}$ of b.w. of black rice bran extract. These dosage levels were based on Nawa (2014) which stated that these dosages were able to decrease the blood glucose levels.

The treatment control group was fed only with pellets and water. Therefore, there was no decrease in the blood glucose levels in this group. On the other hand, the negative control group did not receive any additional treatment after alloxan adminis-tration. Consequently, the negative control group did not show decrease in blood glucose levels, which amounted for $295.33 \pm 157.27 \mathrm{mg} / \mathrm{dL}$ (Figure 1). Based on the results of Wilcoxon statistical test, black rice bran extract treatment doses of 50,100 and $200 \mathrm{mg} / \mathrm{kg}$ of bw can reduce blood glucose levels significantly $(p<0.05)$. This decline was happened in the $4^{\text {th }}, 7^{\text {th }}$, and $10^{\text {th }}$ day after treatment. The largest reduction was occurred on $200 \mathrm{mg} / \mathrm{kg}$ of bw black rice bran extract which accounted for $131.33 \pm 8.08 \mathrm{mg} /$ $\mathrm{dL}$ after $10^{\text {th }}$ day of treatment (Table 1 ).

Flavonoid compounds contained in black rice bran, which is called anthocyanins (Park et al., 2008), caused a decrease in blood glucose concentration. The major anthocyanin

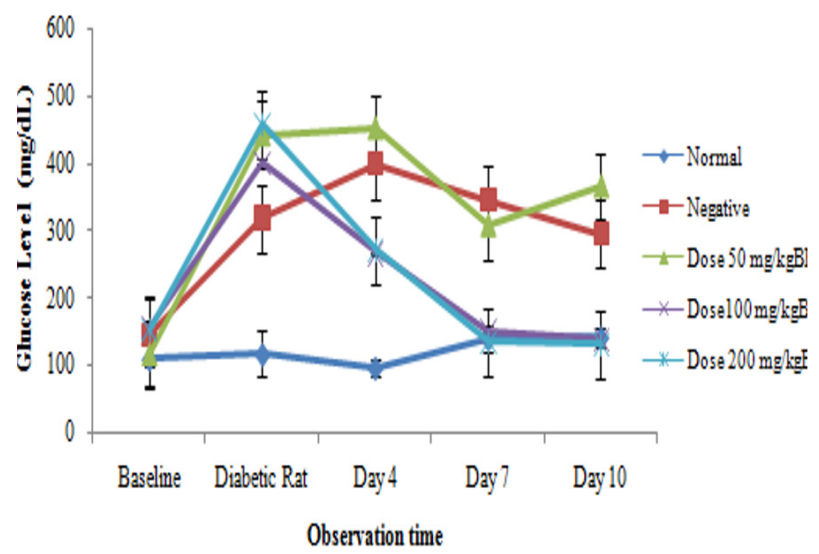

Figure 1. Average of glucose level (mg/dL) before and after treatment extract.

Table 1. Glucose level (mg/dL) before and after treatment extract on 0,4 , and 7 days.

\begin{tabular}{|c|c|c|c|c|c|}
\hline \multirow{2}{*}{ Group } & \multicolumn{5}{|c|}{ Glucose level (mg/dL) } \\
\hline & Baseline & Days 0 & Days 4 & Days 7 & Days 10 \\
\hline \multirow{3}{*}{ Normal group } & 83 & 83 & 90 & 161 & 126 \\
\hline & 92 & 116 & 112 & 122 & 149 \\
\hline & 155 & 152 & 88 & 136 & 152 \\
\hline $\mathbf{X} \pm \mathbf{S D}$ & $110 \pm 39,23$ & $117 \pm 34,51$ & $96,67 \pm 13,31$ & $139,67 \pm 19,75$ & $142,3 \pm 14,22$ \\
\hline II & 190 & 230 & 545 & 469 & 447 \\
\hline \multirow[t]{2}{*}{ Negative group } & 120 & 206 & 137 & 147 & 133 \\
\hline & 132 & 519 & 457 & 418 & 306 \\
\hline $\mathbf{X} \pm \mathbf{S D}$ & $147,33 \pm 37,43$ & $318,33 \pm 174,19$ & $397,67 \pm 214,71$ & $344,67 \pm 173,07$ & $295,33 \pm 157,27$ \\
\hline III & 134 & 414 & 475 & 193 & 345 \\
\hline
\end{tabular}




\begin{tabular}{|c|c|c|c|c|c|c|}
\hline \multirow{2}{*}{\multicolumn{2}{|c|}{ Group }} & \multicolumn{5}{|c|}{ Glucose level (mg/dL) } \\
\hline & & Baseline & Days 0 & Days 4 & Days 7 & Days 10 \\
\hline \multirow[t]{4}{*}{ Extract } & $B B H 50 \mathrm{mg} / \mathrm{kgBB}$ & 100 & 669 & 637 & 547 & 583 \\
\hline & & 116 & 243 & 195 & 184 & 169 \\
\hline & $\mathbf{X} \pm \mathbf{S D}$ & $116,67 \pm 17,00$ & $442 \pm 214,37$ & $451,67 \pm 198,03$ & $308 \pm 207,02$ & $365,67 \pm 207,77$ \\
\hline & IV & 138 & 240 & 214 & 141 & 124 \\
\hline \multirow[t]{4}{*}{ Extract } & $B B H 100 \mathrm{mg} / \mathrm{kgBB}$ & 181 & 474 & 154 & 218 & 152 \\
\hline & & 149 & 486 & 430 & 184 & 141 \\
\hline & $\mathbf{X} \pm \mathbf{S D}$ & $156 \pm 22,33$ & $400 \pm 138,69$ & $266 \pm 145,61$ & $\mathbf{1 5 1} \pm \mathbf{3 8 , 5 8}$ & $139 \pm 14,10$ \\
\hline & V & 118 & 347 & 213 & 108 & 130 \\
\hline \multirow[t]{3}{*}{ Extract } & BBH $200 \mathrm{mg} / \mathrm{kgBB}$ & 136 & 341 & 167 & 122 & 124 \\
\hline & & 204 & 686 & 431 & 174 & 140 \\
\hline & $\mathbf{X} \pm \mathbf{S D}$ & $152,67 \pm 45,35$ & $458 \pm 197,47$ & $270,33 \pm 141,02$ & $134,67 \pm 34,77$ & $131,33 \pm 8,08$ \\
\hline
\end{tabular}

compounds that has activity in lowering blood glucose levels is cyanidine 3-glucoside (Kaneda et al., 2006). In a study conducted by Suryaningrum (2015), cyanidine 3-glucoside obtained from ethanol extract of black rice bran as much as $0.012 \%$ w/w. Moreover, Hadi (2015) concluded that black rice bran has a total anthocyanin content of $3.284 \mathrm{mg} / 100 \mathrm{~g}$. The presence of these compounds can improve the situation of hyperglycemia by increasing glucose transporter type 4 (GLUT4) protein to facilitate the entry of glucose into the cells (Sasaki et al., 2007). Hence, flavonoids have similar ability with insulin in mode of action and repairing pancreatic beta cells. According to Brahmachari (2011), this resemblance of action is happened through a biochemical process by facilitating the transport of glucose into the tissues and promotes the synthesis of glycogen as an energy reserve. Mechanisms of flavonoids as a diabetes drug is by stimulating glucose uptake into peripheral tissues and regulating the level of enzymatic activity that responsible in coordinating the metabolic pathways (Brahmachari, 2011).

In addition, Kaneda et al., (2006) explained that flavonoid anthocyanin also act as an antioxidant which is important in the inhibition of the formation of Reactive Oxygen Species (ROS) by protecting pancreatic beta cells while simultaneously reducing oxidative stress in diabetes melitus (Park et al., 2008; Modak et al., 2007). Thus, antioxidants in black rice bran can prevent complications of diabetes mellitus (Rahimi et al., 2005).

\section{Conclusion}

Based on the results, it can be concluded that black rice bran extract with dose of 200 $\mathrm{mg} / \mathrm{kg}$ of b.w. was able to lower blood glucose levels up to $131.33 \pm 8.08 \mathrm{mg} / \mathrm{dL}$ after 10 days of treatment.

\section{References}

Brahmachari, G., 2011, Bio-flavonoids with promising anti- diabetic potentials : A critical survey, Anti-diabetic bio-flavonoids, 661 (2), 187-212.

Campbell, Reece, \& Mitchell, 2004, Biologi. Edisi Kelima Jilid 3, Alih Bahasa: Wasmen Manalu, Editor: Amalia Safitri, Jakarta, Erlangga.

Dwinani, N., S., 2010, Kemampuan Estrak Etanol Bekatul Beras Hitam Dalam Menurunkan Kadar Glukosa Darah Pada Tikus Nefropati Diabetes, Skripsi, Fakultas Farmasi, Universitas Muhammadiyah Surakarta.

Etuk \& Muhammed, 2010, Evidence Based Analysis of Chemical Method of Induction of Diabetes Mellitus in Experimental Animals, Society of Applied Sciences, 1 (2), 331-336.

Hadi, A., 2015, Aktivitas Antioksidan Etanol Ekstrak Bekatul Beras Hitam (Oryzae sativa L. 
indica) dan Bekatul Beras Merah (Oryza nivara) Beserta Penetapan Total Antosianin, Skripsi, Fakultas Farmasi, Universitas Muhammadiyah Surakarta.

Haznam, M.W., 1991, Endokrinologi, 37, Percetakan Angkasa Offset.

Hu, C. et al., 2003, Black Rice (Oryza sativa L. indica) Pigmented Fraction Suppresses both Reactive Oxygen Species and Nitric Oxide in Chemical and Biological Model Systems, Journal of Agricultural and Food Chemistry, 51, 5271-5277.

Kaneda, I., Kubo, F. \& Sakurai, H., 2006, Antioxidative Compounds in the Extracts of Black Rice Brans, Journal of Health Science, 52 (5), 495-511.

Malviya, N., Jain, S., \& Malviya, S., 2010, Review Antidiabetic Potential of Medicinal Plants, Acta Poloniae Pharmaceutica-Drug Research, 67 (2), 113-118.

Modak, M., Dixit, P., Londhe, J., Ghaskadbi, S., \& Devasagayam., 2007, Indian Herbs and Herbal Drugs Used for The Treatment of Diabetes. J. Clin. Biochem. Nutr, 40, 163-173.

Nontasan, Moongngarma, \& Deeseenthumb, 2012, Application of Functional Colorant Prepared from Black Rice Bran in Yogurt, Journal Article, Procedia 2 (2012) 62-67.

Park et al., 2008, Isolation of Anthocyanin from Black Rice (Heugjinjubyeo) and Screening of its Antioxidant Activities, Korea Journal Microbial Biotecnology, 36 (1), 55-60.

Sasaki, R. et al., 2007, Cyanidin 3-glucoside ameliorates hyperglycemia and insulin sensitivity due to down regulation of retinol binding protein 4 expression in diabetic mice, Biochemical Pharmacology, 74, 1619-1627.

Suliartini, N. W. S., Sadimantara, G. R., Wijayanto, T., \& Muhidin., 2011, 43 pengujian kadar antosianin padi gogo beras merah hasil koleksi plasma nutfah sulawesi tenggara, Crop Argo, 4 (2), 43-48.

Suryaningrum, A., 2015, Penetapan Kadar Sianidin-3-O-Glukosida Dalam Ekstrak Etanol 96\% Bekatul Beras Hitam (Oryza Sativa L. Indica) Dan Bekatul Beras Merah (Oryza Nivara) Menggunakan HPLC-PDA, Skripsi, Fakultas Farmasi, Universitas Muhammadiyah Surakarta.

Suyono, S. 1995, Kecenderungan Peningkatan Jumlah Pasien Diabetes. In : Soegondo, S., Soewondo, P., Subekti, I. (eds.) Diabetes Melitus Penatalaksanaan Terpadu, 5-6, Jakarta, FKUI.

Suzana, L., 1992, Mempelajari Substitusi Parsial Dedak Padi (Bekatul) terhadap Tepung Terigu (Triticum vulgare), sebagai Sumber Dietary Fiber dan Niasin, dalam Pembuatan Roti Manis dan Biskuit, Skripsi, Fakultas Pertanian, Universitan Institut Pertanian Bogor.

Szkudelski, T., 2001, The Mechanism of Alloxan and Streptozotocin Action in B Cells of The Rat Pancreas, Physiological Research, 50: 536-546.

Tapas, A. R., Sakarkar, D. M. \& Kakde, R. B., 2008, Flavonoids as Nutraceuticals: A Review, Tropical Journal of Pharmaceutical Research, 7 (3): 1089-1099.

Tjokoprawiro, A., 1999, Diabetes Mellitus: Klasifikasi, Diagnosis dan Terapi, 8, Jakarta, Gramedia Pustaka Utama.

Utaminingsih, E., 2015, Pengaruh Pemberian Ekstrak Bekatul Beras Hitam (Black Rice Bran) Terhadap Kadar Insulin Darah Pada Tikus Hiperglikemik, Skripsi, Fakultas Farmasi, Universitas Muhammadiyah Surakarta.

Wild, S. et al., 2004, Global Prevalence of Diabetes Estimates for the year 2000 and projections for 2030, Diabetes Care, 27 (5), 1047-1053. 